\title{
The relationship between hand osteoarthritis and serum leptin concentration in participants of the Third National Health and Nutrition Examination Survey
}

Mei Massengale ${ }^{1,2}$, William M Reichmann ${ }^{3,4,5}$, Elena Losina ${ }^{1,2,3,4,5}$, Daniel H Solomon ${ }^{1,2,6}$ and Jeffrey N Katz ${ }^{1,2,3,4,7^{*}}$

\begin{abstract}
Introduction: Leptin has been suspected to contribute to the development of osteoarthritis (OA). However, this hypothesis has not been tested in large-scale hand OA cohorts. Our study aimed to determine whether there is a cross-sectional relationship between serum leptin levels and hand OA in a population-based sample of US adults.

Method: We used the Third National Health and Nutrition Examination Survey (NHANES III), a national crosssectional population-based survey, to study the relationship between hand OA and serum leptin concentration. We applied previously established classification criteria for hand OA. Patients with rheumatoid arthritis were excluded. Potential confounders included sex, body mass index, the presence of polyarticular OA, diabetes, and total cholesterol. We estimated unadjusted mean leptin concentration by hand OA status and by all confounders. We further developed a linear regression model to assess mean leptin levels, adjusted for appropriate confounders.

Results: Of 2,477 subjects in the NHANES III sample that had a hand examination and did not have rheumatoid arthritis, 1,056 (42.6\%) had a leptin measurement and were included in the analysis. Subjects with and without leptin measurement had similar demographic characteristics. We did not find any significant differences in mean serum leptin levels in subjects with symptomatic hand $\mathrm{OA}(7.38 \mathrm{ng} / \mathrm{ml}$ in males $(95 \%$ confidence interval $(\mathrm{Cl})=$ $5.31,9.46)$ and $21.55 \mathrm{ng} / \mathrm{ml}$ in females $(95 \% \mathrm{Cl}=17.08,26.02))$, asymptomatic hand $\mathrm{OA}(6.69 \mathrm{ng} / \mathrm{ml}$ in males $(95 \%$ $\mathrm{Cl}=5.19,8.18)$ and $17.09 \mathrm{ng} / \mathrm{ml}$ in females $(95 \% \mathrm{Cl}=15.00,19.18))$, and no hand $\mathrm{OA}(8.22 \mathrm{ng} / \mathrm{ml}$ in males $(95 \% \mathrm{Cl}$ $=7.47,8.97)$ and $20.77 \mathrm{ng} / \mathrm{ml}$ in females $(95 \% \mathrm{Cl}=18.01,23.53))$ in the unadjusted analysis. In a multivariable linear regression model that included variables of hand OA status, age, race/ethnicity, and obesity status, we found no statistically significant association between serum leptin and hand OA status.
\end{abstract}

Conclusions: In this cross-sectional study of a large representative US cohort, we did not find any evidence to support the hypothesis that serum leptin is associated with hand OA.

\section{Introduction}

Hand osteoarthritis (OA) is a common joint disease worldwide, resulting in weakened grip strength and significant functional disability [1]. As nonweight-bearing joints, the hand is a useful target for the study of nonmechanical risk factors for OA pathogenesis [2-10].

\footnotetext{
* Correspondence: jnkatz@partners.org

'Division of Rheumatology, Brigham and Women's Hospital, 75 Francis Street, Boston, MA 02115, USA

Full list of author information is available at the end of the article
}

Obesity has been observed to have associations with OA development in nonweight-bearing joints as well as in weight-bearing joints [11-14]. Adipokine hormones such as leptin have long been thought to contribute to OA pathogenesis directly, independent of the mechanical effect of obesity $[3,4,11,15]$. Leptin, a small polypeptide, is predominantly produced in white adipose tissue and regulates food intake and energy expenditure. Leptin has also been increasingly recognized to play a role in inflammation, angiogenesis, as well as cartilage and

\section{Ciomed Central}


bone metabolism, and thus has been implicated in the development of osteoarthritis [3,15-18].

Studies have suggested a possible relationship between leptin and OA of weight-bearing joints $[15,16]$. However, there have been few studies of nonweight-bearing joints - such as the hand joints - to examine nonmechanical risk factors for OA. Leptin was not associated with hand OA progression in a recent study of fewer than 300 subjects [19]. To date, no study has examined the cross-sectional association between leptin and hand OA in a population-based sample. The objective of our study was to determine whether a cross-sectional relationship exists between leptin and OA in a US population-based sample of adults at least 60 years of age.

\section{Materials and methods Study sample}

We used data from the Third National Health and Nutrition Examination Survey (NHANES III), a national cross-sectional population-based survey conducted from 1988 to 1994 to assess the health and nutrition of the non-institutionalized US population. Survey data, which include demographics, health status, health disorders, and behaviors among others, were collected by household interviews. Physical examinations and blood draws were also performed by physicians at mobile examination centers. For this analysis we used data from the demographic file [20], the examination file [21], and the serum leptin file [22]. Our analysis was restricted to subjects surveyed from 1991 to 1994 and age 60 years or older because NHANES III conducted the hand examination only on these subjects.

NHANES III subjects were randomly assigned to be tested for leptin [22]. Subjects with rheumatoid arthritis were excluded from the analysis, based on clinical information collected at the physician interview, examination and criteria used by Dillon, Rasch and colleagues $[23,24]$. Institutional Review Board approval was not necessary because the National Health and Nutrition Examination Survey is a publically available database.

\section{Data elements}

\section{Assessment of hand osteoarthritis}

We applied a previously developed algorithm for defining hand $\mathrm{OA}$ in the National Health and Nutrition Examination Survey. Dillon and colleagues developed a definition of hand OA in the National Health and Nutrition Examination Survey database that is modeled on the American College of Rheumatology definition [23]. The American College of Rheumatology criteria and the NHANES III definition differ slightly, as shown in Table $1[23]$. We defined asymptomatic hand OA as cases fulfilling criteria 2 to 4 but not criterion 1 . In the group without hand OA, subjects did not have symptoms or physical examination evidence of hand OA. Hand radiographs were not released from NHANES III for analysis. Leptin

Human studies have shown that leptin levels probably peak between 12 midnight and 2:30 am, and are lowest between noon and early afternoon [25]. In NHANES III, leptin was measured in the morning after an 8-hour overnight fast. Leptin has been shown to remain stable when stored frozen for many years [26-29]. The laboratory analysis for serum leptin was performed by Linco Research, Inc. (St. Louis, MO, USA) using a radioimmunoassay with a rabbit polyclonal antibody against highly purified recombinant human leptin. Detectable concentrations of the assay range from 0.5 to $100 \mathrm{fg} / \mathrm{l}$. Withinassay and between-assay reliability coefficients of variations range from 3.4 to $8.3 \%$ for radioimmunoassay and from 3.6 to $6.2 \%$ for western blot [22].

\section{Potential confounders}

We hypothesized that age, sex, race/ethnicity, body mass index (BMI), the presence of polyarticular OA, diabetes, and total cholesterol may confound the relationship between leptin and hand OA. We thus accounted for

Table 1 Hand osteoarthritis classification criteria

\begin{tabular}{|c|c|}
\hline American College of Rheumatology criteria & $\begin{array}{l}\text { Criteria for symptomatic hand OA using NHANES III data adapted from Dillon and } \\
\text { colleagues }^{\mathrm{a}}\end{array}$ \\
\hline $\begin{array}{l}\text { Hand } \mathrm{OA} \text { is identified if participants meet } \\
\text { criteria } 1 \text { to } 4 \text { : }\end{array}$ & Hand $O A$ is identified if participants meet criteria 1 to 4 : \\
\hline 1. Hand pain, aching, or stiffness & 1. Ever had history of hand pain, aching, stiffness lasting more than 6 weeks \\
\hline $\begin{array}{l}\text { 2. Hard tissue enlargement of two or } \\
\text { more of } 10 \text { selected joints }\end{array}$ & $\begin{array}{l}\text { 2. At least two sites of hard tissue enlargement, with the combination of first CMC and one } \\
\text { other site with Heberden's or Bouchard's nodes }\end{array}$ \\
\hline $\begin{array}{l}\text { 3. Fewer than three swollen metacarpal- } \\
\text { phalangeal joints }\end{array}$ & $\begin{array}{l}\text { 3. Fewer than three swollen metacarpal-phalangeal joints or participants do not meet the } \\
\text { criteria for rheumatoid arthritis }\end{array}$ \\
\hline $\begin{array}{l}\text { 4a. Either hard tissue enlargement of two } \\
\text { or more DIP joints, or }\end{array}$ & 4. The presence of bilateral Heberden's nodes at any site \\
\hline 4b. deformity of one out of 10 joints & $\begin{array}{l}\text { (would remove this number " } 5 \text { " as this is not one of the criteria used in Dillon's NHANES study. } \\
\text { The text was put here to compare with ACR criteria. No such data available from NHANES III }\end{array}$ \\
\hline
\end{tabular}

CMC, carpometacarpal; DIP, distal interphalangeal joint; NHANES III, Third National Health and Nutrition Examination Survey. ${ }^{\mathrm{a}}$ This is the classification used to define symptomatic hand osteoarthritis $(O A)$ in the present study. Adapted from Dillon and colleagues [23]. 
these variables in the analysis. Age was classified into three groups; 60 to 69 years, 70 to 79 years, and $80+$ years. We classified a subject's race/ethnicity as nonHispanic white, non-Hispanic black, Hispanic, or other. We classified BMI as normal $\left(<25 \mathrm{~kg} / \mathrm{m}^{2}\right)$, overweight $\left(25\right.$ to $\left.29.99 \mathrm{~kg} / \mathrm{m}^{2}\right)$, and obese $\left(\geq 30 \mathrm{~kg} / \mathrm{m}^{2}\right)$. Polyarticular OA was defined as the presence of radiographic knee OA with a Kellgren-Lawrence grade $\geq 2$ in at least one knee in addition to having either symptomatic hand OA or asymptomatic hand OA. Total cholesterol was classified as desirable $(<200)$, borderline high (200 to 239), and high $(\geq 240)$.

\section{Statistical analysis}

To ensure that the sample of subjects with a leptin measurement did not differ from the sample of subjects without a leptin measurement, we compared potential confounders for those with a leptin measurement and for those without a leptin measurement. The remaining analyses were performed on those with a hand examination and a leptin measurement. We calculated percentages by hand OA status for all potential confounders. We estimated unadjusted mean leptin levels by hand OA status and the other potential confounders stratified by sex. We stratified analyses of leptin by sex because the mean and variance of serum leptin concentration was much greater among females than in males. We further applied linear regression to estimate the adjusted mean leptin by hand OA status stratified by sex. To fit the most parsimonious model, we only included potential confounders in the final model if they reached statistical significance at an alpha level of 0.05 . We used SAS statistical software (version 9.2; SAS Institute, Inc, Cary, North Carolina, U.S.A.) to perform all analyses. To account for the complex multistage survey design and to obtain estimates representative of the non-institutionalized US population, we used survey procedures within SAS and weighted the analyses using the appropriate survey sampling weight.

\section{Results}

Of the 2,589 subjects who had interviews and hand examinations, examination data were complete in 2,498. Nineteen patients with rheumatoid arthritis were excluded. Of 2,477 subjects that were eligible for the analysis, 1,056 (42.6\%) had a serum leptin measurement and comprised our sample. Subjects with leptin measurements and those who did not have leptin measurements were similar with respect to demographic factors (age, sex, race, BMI) (see Additional file 1). Among those in our final sample, hand OA was symptomatic in 90 patients $(8.5 \%)$, asymptomatic in 376 patients (35.6\%), and not present in 590 patients (55.9\%).
The mean age of the final sample was $70.3 \pm 8.2$ years and the mean BMI of the final sample was $26.4 \pm 4.9$ $\mathrm{kg} / \mathrm{m}^{2}$. Subjects with hand OA (both symptomatic and asymptomatic) were more likely to be female than those without hand OA. Subjects with symptomatic hand OA were more likely to be overweight (45\%) and obese (25\%) than those with asymptomatic hand OA $(39 \%$ overweight and $16 \%$ obese). Detailed data on the demographic and clinical characteristics of our sample stratified by hand OA status are shown in Table 2 .

Unadjusted mean leptin levels stratified by sex and all potential confounders are shown in Table 3. Among males, the unadjusted mean leptin level did not vary substantially by hand OA status. Those with no hand OA had a mean leptin of 8.22 (95\% confidence interval $(\mathrm{CI})=7.47,8.97)$ compared with $7.38(95 \% \mathrm{CI}=5.31$, 9.46) for those with symptomatic hand OA and 6.69 $(95 \% \mathrm{CI}=5.19,8.18)$ for those with asymptomatic hand OA. Among females, the unadjusted mean leptin did vary slightly by hand $\mathrm{OA}$ status, with those with asymptomatic hand $\mathrm{OA}$ having the lowest mean leptin at $17.09(95 \% \mathrm{CI}=15.00,19.18)$. However, all of the $95 \%$ CIs overlapped. The mean leptin for females with symptomatic hand $\mathrm{OA}$ was $21.55(95 \% \mathrm{CI}=17.08,26.02)$ and for no hand OA was 20.77 (95\% CI $=18.01,23.53)$. Mean leptin levels increased as BMI increased for both males and females.

Results of the linear regression showed similar findings to the unadjusted analysis. The final model included hand OA status, age, and obesity status. Race/ ethnicity, diabetes, polyarticular OA, and total cholesterol were not included in the final model. Among males, the adjusted mean leptin for those with symptomatic hand OA was $8.88(95 \% \mathrm{CI}=7.08,10.67)$ compared with $8.21(95 \% \mathrm{CI}=6.62,9.80)$ for those with asymptomatic hand $\mathrm{OA}$ and $9.40(95 \% \mathrm{CI}=8.59,10.21)$ for those with no hand OA. Similarly, among females, the adjusted mean leptin for those with symptomatic hand OA was 21.89 (95\% CI $=18.70,25.07)$ compared with 20.13 (95\% CI $=18.32,21.95)$ for those with asymptomatic hand $\mathrm{OA}$ and $23.09(95 \% \mathrm{CI}=21.83$, 24.34) for those with no hand OA (Table 4). None of these differences in adjusted mean leptin levels was statistically significant (all $P>0.05$ ).

\section{Discussion}

The present study used data from NHANES III to describe the cross-sectional relationship between leptin and hand OA. The study did not provide evidence to support the hypothesis that hand OA is associated with increased serum leptin level. Stratified and multivariable analyses did not show evidence of a difference in leptin levels in the symptomatic hand OA, asymptomatic hand $\mathrm{OA}$, and no hand $\mathrm{OA}$ groups. The multivariable 
Table 2 Demographic characteristics of the sample by hand osteoarthritis status

\begin{tabular}{|c|c|c|c|}
\hline & Symptomatic hand OA & Asymptomatic hand $\mathrm{OA}$ & No hand $O A$ \\
\hline \multicolumn{4}{|l|}{ Age } \\
\hline 60 to 69 years & $41(45 \%)$ & $138(45 \%)$ & $309(58 \%)$ \\
\hline 70 to 79 years & $35(46 \%)$ & $140(39 \%)$ & $169(28 \%)$ \\
\hline $80+$ years & $14(9 \%)$ & $98(17 \%)$ & $112(15 \%)$ \\
\hline \multicolumn{4}{|l|}{ Sex } \\
\hline Male & $36(34 \%)$ & $159(37 \%)$ & $315(49 \%)$ \\
\hline Female & $54(66 \%)$ & $217(63 \%)$ & $275(51 \%)$ \\
\hline \multicolumn{4}{|l|}{ Race/ethnicity } \\
\hline Non-Hispanic white & $47(85 \%)$ & $251(90 \%)$ & $301(79 \%)$ \\
\hline Non-Hispanic black & $17(9 \%)$ & $49(5 \%)$ & $124(8 \%)$ \\
\hline Hispanic & $26(5 \%)$ & $75(5 \%)$ & $153(9 \%)$ \\
\hline Other & $0(0 \%)$ & $1(0 \%)$ & $12(4 \%)$ \\
\hline \multicolumn{4}{|l|}{ BMI status } \\
\hline Normal $\left(\mathrm{BMl}<25 \mathrm{~kg} / \mathrm{m}^{2}\right)$ & $22(31 \%)$ & $152(45 \%)$ & $208(42 \%)$ \\
\hline Overweight $\left(25 \leq \mathrm{BMl}<30 \mathrm{~kg} / \mathrm{m}^{2}\right)$ & $39(45 \%)$ & $145(39 \%)$ & $212(35 \%)$ \\
\hline Obese $\left(\mathrm{BMI} \geq 30 \mathrm{~kg} / \mathrm{m}^{2}\right)$ & $25(25 \%)$ & $50(16 \%)$ & $133(23 \%)$ \\
\hline \multicolumn{4}{|l|}{ Radiographic knee OA } \\
\hline Yes & $36(31 \%)$ & $130(32 \%)$ & 177 (30\%) \\
\hline No & 47 (69\%) & $234(68 \%)$ & $391(70 \%)$ \\
\hline \multicolumn{4}{|l|}{ Diabetes } \\
\hline Yes & $19(15 \%)$ & $36(8 \%)$ & $81(11 \%)$ \\
\hline No & $71(85 \%)$ & $339(92 \%)$ & $508(89 \%)$ \\
\hline \multicolumn{4}{|l|}{ Total cholesterol } \\
\hline Desirable $(<200)$ & $27(26 \%)$ & $120(27 \%)$ & $190(29 \%)$ \\
\hline Borderline high (200 to 239) & $32(39 \%)$ & $140(40 \%)$ & $218(39 \%)$ \\
\hline High ( $\geq 240)$ & 31 (35\%) & $113(32 \%)$ & $173(32 \%)$ \\
\hline
\end{tabular}

Data presented as $n$ (\%). Percentages are weighted using Third National Health and Nutrition Examination Survey sampling weights. BMI, body mass index; OA, osteoarthritis.

analyses adjusted for age, race/ethnicity, BMI status, and the presence of polyarticular $\mathrm{OA}$ as indicated by radiographic knee OA, diabetes status, and serum cholesterol.

Our analyses have several important strengths. NHANES III has a large sample size, making it unlikely that we simply missed an effect due to chance. Also, selection bias is unlikely because the NHANES III sample was representative of the US population. Lastly, since we accounted for the complex sample design and used the sampling weights, the estimates are representative of the US population [22].

The study also has limitations. A possible explanation for our null result is that the association between hand $\mathrm{OA}$ and leptin is complex and cannot be assessed using a cross-sectional sample. Leptin may be associated with hand $\mathrm{OA}$ at one time point of its development only. However, in the longitudinal study carried out by Yusuf and colleagues, serum leptin was not found to be associated with hand OA progression in 6-year follow-up of 248 participants [19]. The paper by Yusuf and colleagues used a longitudinal design with a radiographic case definition [19]. In the present cross-sectional study, we measured hand OA by an algorithm that incorporates symptoms and physical examination. These two approaches are complementary, and neither supports an association between serum leptin and hand OA.

Another explanation for the null result is the possible misclassification of hand OA in NHANES III. There is no gold standard for the diagnosis of hand OA. Our use of the classification criteria suggested by Dillon and colleagues could have resulted in misclassification. Many patients with early or developing OA start with pain, followed by delayed onset of bony enlargement for months or years. Using our criteria, these subjects would be categorized as having no OA. Misclassification of this sort would tend to bias associations toward the null and could indeed play a role in our negative findings.

As expected, our results confirmed that leptin is associated with gender and BMI status, consistent with prior animal and human studies [30-33]. These findings provide face validity for the leptin measurements. Our study is the largest population-based confirmation of such a relationship in humans, with prior studies in the 
Table 3 Unadjusted mean leptin by sex for hand osteoarthritis status and potential confounders in NHANES III

\begin{tabular}{|c|c|c|c|c|}
\hline & \multicolumn{2}{|c|}{ Male } & \multicolumn{2}{|c|}{ Female } \\
\hline & $\bar{n}$ & Mean $^{a}(95 \% \mathrm{Cl})$ & $n$ & $\operatorname{Mean}^{\mathrm{a}}(95 \% \mathrm{Cl})$ \\
\hline Overall & 510 & $7.66(7.11,8.21)$ & 546 & $19.24(17.19,21.29)$ \\
\hline \multicolumn{5}{|l|}{ Hand OA status } \\
\hline Symptomatic hand $\mathrm{OA}$ & 36 & $7.38(5.31,9.46)$ & 54 & $21.55(17.08,26.02)$ \\
\hline Asymptomatic hand OA & 159 & $6.69(5.19,8.18)$ & 217 & $17.09(15.00,19.18)$ \\
\hline No hand $O A$ & 315 & $8.22(7.47,8.97)$ & 275 & $20.77(18.01,23.53)$ \\
\hline \multicolumn{5}{|l|}{ Age } \\
\hline 60 to 69 years & 255 & $7.53(6.83,8.22)$ & 233 & $21.43(18.73,24.13)$ \\
\hline 70 to 79 years & 147 & $7.88(6.47,9.29)$ & 197 & $17.60(14.47,20.73)$ \\
\hline $80+$ years & 108 & $7.66(6.24,9.07)$ & 116 & $16.00(12.73,19.28)$ \\
\hline \multicolumn{5}{|l|}{ Race/ethnicity } \\
\hline Non-Hispanic white & 273 & $7.62(7.06,8.17)$ & 326 & $18.73(16.52,20.95)$ \\
\hline Non-Hispanic black & 89 & $7.30(5.61,8.99)$ & 101 & $24.39(21.52,27.25)$ \\
\hline Hispanic & 139 & $8.74(6.24,11.25)$ & 115 & $19.34(13.94,24.74)$ \\
\hline Other & 9 & $7.42(6.31,8.53)$ & 4 & $19.83(-2.88,42.54)$ \\
\hline \multicolumn{5}{|l|}{ BMI status } \\
\hline Normal $\left(\mathrm{BMl}<25 \mathrm{~kg} / \mathrm{m}^{2}\right)$ & 183 & $5.00(4.30,5.70)$ & 199 & $11.54(10.30,12.77)$ \\
\hline Overweight $\left(25 \leq \mathrm{BMl}<30 \mathrm{~kg} / \mathrm{m}^{2}\right)$ & 217 & $7.73(6.75,8.70)$ & 179 & $19.65(17.68,21.63)$ \\
\hline Obese (BMI $\left.\geq 30 \mathrm{~kg} / \mathrm{m}^{2}\right)$ & 90 & $13.03(11.03,15.03)$ & 118 & $34.55(31.22,37.88)$ \\
\hline \multicolumn{5}{|l|}{ Radiographic knee OA } \\
\hline Yes & 132 & $8.99(7.53,10.45)$ & 211 & $23.31(19.55,27.08)$ \\
\hline No & 357 & $7.09(6.59,7.60)$ & 315 & $16.93(14.99,18.87)$ \\
\hline \multicolumn{5}{|l|}{ Diabetes } \\
\hline Yes & 64 & $8.69(7.10,10.27)$ & 72 & $20.62(16.47,24.76)$ \\
\hline No & 445 & $7.55(7.02,8.08)$ & 473 & $19.1(17.13,21.08)$ \\
\hline \multicolumn{5}{|l|}{ Total cholesterol } \\
\hline Desirable $(<200)$ & 201 & $7.24(6.33,8.14)$ & 136 & $14.87(12.01,17.73)$ \\
\hline Borderline high (200 to 239) & 193 & $7.36(6.66,8.07)$ & 197 & $18.99(16.40,21.58)$ \\
\hline High ( $\geq 240)$ & 113 & $8.18(6.92,9.44)$ & 204 & $22.20(18.99,25.41)$ \\
\hline
\end{tabular}

BMI, body mass index; $\mathrm{Cl}$, confidence interval; OA, osteoarthritis. ${ }^{a}$ Means are weighted using Third National Health and Nutrition Examination Survey (NHANES III) sampling weights.

literature having sample sizes ranging from 87 to 426 subjects [30-33].

\section{Conclusions}

We did not find a cross-sectional association between hand OA and serum leptin in our sample. Prospective studies are needed to further evaluate the possibility

Table 4 Adjusted mean leptin by sex and hand osteoarthritis status

\begin{tabular}{lllll}
\hline & \multicolumn{3}{l}{ Male } & \multicolumn{3}{l}{ Female } \\
\cline { 2 - 5 } Hand OA status & Mean $^{\mathbf{a}}$ & $\mathbf{9 5 \%} \mathbf{C l}$ & Mean $^{\mathbf{a}}$ & $\mathbf{9 5 \%} \mathbf{C l}$ \\
\hline Symptomatic hand OA & 8.88 & $7.09,10.67$ & 21.89 & $18.70,25.08$ \\
Asymptomatic hand OA & 8.21 & $6.62,9.80$ & 20.13 & $18.32,21.94$ \\
No hand OA & 9.40 & $8.59,10.21$ & 23.09 & $21.84,24.34$ \\
\hline
\end{tabular}

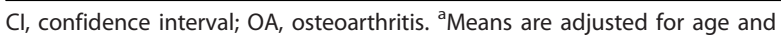
obesity status, and are weighted using Third National Health and Nutrition Examination Survey sampling weights. that elevated leptin levels predate the onset or progression of clinically apparent hand OA.

\section{Additional material}

Additional file 1: table presenting characteristics of the study sample by serum leptin measurement status, comparing demographic, disease, and confounders' characteristics of the sample with leptin measurement with the sample without leptin measurement in NHANES III.

\footnotetext{
Abbreviations

BMI: body mass index; Cl: confidence interval; NHANES III: Third National Health and Nutrition Examination Survey; OA: osteoarthritis.

\section{Acknowledgements}

The present work was conducted with support from Harvard Catalyst | The Harvard Clinical and Translational Science Center (NIH Award \#UL1 RR 025758 and financial contributions from Harvard University and its affiliated academic healthcare centers). The content is solely the responsibility of the authors and does not necessarily represent the official views of Harvard
} 
Catalyst, Harvard University and its affiliated academic healthcare centers, the National Center for Research Resources, or the National Institutes of Health. This study was also supported by NIH T32 AR007530-27, NIH T32 AR 055885, NIH P60 AR 47782, NIH K24 AR 057827, and NIH K24 AR 055989. The study sponsors had no role in the study design, collection, analysis and interpretation of data, in the writing of the manuscript, or in the decision to submit the manuscript for publication.

\section{Author details}

'Division of Rheumatology, Brigham and Women's Hospital, 75 Francis Street, Boston, MA 02115, USA. ${ }^{2}$ Harvard Medical School, Longwood Avenue, Boston, MA 02115, USA. ${ }^{3}$ Department of Orthopedic Surgery, Brigham and Women's Hospital, 75 Francis Street, Boston, MA 02115, USA. ${ }^{4}$ Orthopaedic and Arthritis Center for Outcomes Research, Brigham and Women's Hospital, 75 Francis Street, Boston, MA 02115, USA. ${ }^{5}$ Department of Biostatistics, Boston University School of Public Health, 715 Albany Street, Boston, MA 02118, USA. 'Division of Pharmacoepidemiology and Pharmacoeconomics, Brigham and Women's Hospital/Harvard Medical School, 75 Francis Street, Boston, MA 02115, USA. ${ }^{7}$ Department of Epidemiology, Harvard School of Public Health, 677 Huntington Avenue, Boston, MA 02115, USA.

\section{Authors' contributions}

All authors read and approved the manuscript for publication. MM was involved in the conception and design of the study, analysis and interpretation of the data, drafting the article, and critical revision of the article for important intellectual content. WMR was involved in the analysis and interpretation of data, drafting the article, critical revision of the article for important intellectual content, statistical expertise, and collection and assembly of data. EL was involved in conception and design of the study, analysis and interpretation of the data, critical revision of the article for important intellectual content, and statistical expertise. DHS was involved in the analysis and interpretation of the data and critical revision of the article for important intellectual content. JNK was involved in conception and design of the study, analysis and interpretation of the data, critical revision of the article for important intellectual content, final approval of the article, and takes responsibility for the integrity of the work as a whole, from inception to finished article.

\section{Competing interests}

The authors declare that they have no competing interests.

Received: 10 February 2012 Revised: 29 March 2012

Accepted: 31 May 2012 Published: 31 May 2012

\section{References}

1. Bagis S, Sahin G, Yapici Y, Cimen OB, Erdogan C: The effect of hand osteoarthritis on grip and pinch strength and hand function in postmenopausal women. Clin Rheumatol 2003, 22:420-424

2. Abramson SB, Attur M: Developments in the scientific understanding of osteoarthritis. Arthritis Res Ther 2009, 11:227.

3. Dumond H, Presle N, Terlain B, Mainard D, Loeuille D, Netter P, Pottie P: Evidence for a key role of leptin in osteoarthritis. Arthritis Rheum 2003, 48:3118-3129

4. Vuolteenaho K, Koskinen A, Kukkonen M, Nieminen R, Päivärinta U, Moilanen T, Moilanen E: Leptin enhances synthesis of proinflammatory mediators in human osteoarthritic cartilage - mediator role of NO in leptin-induced PGE2, IL-6, and IL-8 production. Mediators Inflamm 2009, 2009:345838.

5. Magnano MD, Chakravarty EF, Broudy C, Chung L, Kelman A, Hillygus J, Genovese MC: A pilot study of tumor necrosis factor inhibition in erosive/inflammatory osteoarthritis of the hands. J Rheumatol 2007, 34:1323-1327.

6. Dequeker J, Aerssens J, Luyten FP: Osteoarthritis and osteoporosis: clinical and research evidence of inverse relationship. Aging Clin Exp Res 2003, 15:426-439.

7. Hochberg MC, Lethbridge-Cejku M, Tobin JD: Bone mineral density and osteoarthritis: data from the Baltimore Longitudinal Study of Aging. Osteoarthritis Cartilage 2004, 12(Suppl A):S45-S48.

8. Lippiello L, Walsh T, Fienhold M: The association of lipid abnormalities with tissue pathology in human osteoarthritic articular cartilage. Metabolism 1991, 40:571-576.
9. Gkretsi V, Simopoulou T, Tsezou A: Lipid metabolism and osteoarthritis: lessons from atherosclerosis. Prog Lipid Res 2011, 50:133-140.

10. Tsezou A, lliopoulos D, Malizos KN, Simopoulou T: Impaired expression of genes regulating cholesterol efflux in human osteoarthritic chondrocytes. J Orthop Res 2010, 28:1033-1039.

11. Filková M, Lisková M, Hulejová H, Haluzík M, Gatterová J, Pavelková A, Pavelka K, Gay S, Müller-Ladner U, Senolt L: Increased serum adiponectin levels in female patients with erosive compared with non-erosive osteoarthritis. Ann Rheum Dis 2009, 68:295-296.

12. Marks $R$, Allegrante JP: Body mass indices in patients with disabling hip osteoarthritis. Arthritis Res 2002, 4:112-116.

13. Cicuttini FM, Baker JR, Spector TD: The association of obesity with osteoarthritis of the hand and knee in women: a twin study. J Rheumatol 1996, 23:1221-1226.

14. Oliveria SA, Felson DT, Cirillo PA, Reed JI, Walker AM: Body weight, body mass index, and incident symptomatic osteoarthritis of the hand, hip, and knee. Epidemiology 1999, 10:161-166.

15. Stannus OP, Jones G, Quinn SJ, Cicuttini FM, Dore D, Ding C: The association between leptin, interleukin-6, and hip radiographic osteoarthritis in older people: a cross-sectional study. Arthritis Res Ther 2010, 12:R95.

16. Berry PA, Jones SW, Cicuttini FM, Wluka AE, Maciewicz RA: Temporal relationship between serum adipokines, biomarkers of bone and cartilage turnover, and cartilage volume loss in a population with clinical knee osteoarthritis. Arthritis Rheum 2011, 63:700-707.

17. Zhang $Y$, Proenca R, Maffei M, Barone M, Leopold L, Friedman JM: Positional cloning of the mouse obese gene and its human homologue. Nature 1994, 372:425-432.

18. Sierra-Honigmann MR, Nath AK, Murakami C, García-Cardeña G, Papapetropoulos A, Sessa WC, Madge LA, Schechner JS, Schwabb MB, Polverini PJ, Flores-Riveros JR: Biological action of leptin as an angiogenic factor. Science 1998, 281:1683-1686

19. Yusuf E, loan-Facsinay A, Bijsterbosch J, Klein-Wieringa I, Kwekkeboom J, Slagboom PE, Huizinga TW, Kloppenburg M: Association between leptin, adiponectin and resistin and long-term progression of hand osteoarthritis. Ann Rheum Dis 2011, 70:1282-1284.

20. US Department of Health and Human Services: National Center for Health Statistics: Third National Health and Nutritional Examination Survey, 1988-1994 NHANES III. Demographic Data File Hyattsville, MD: Centers for Disease Control and Prevention; 1997.

21. US Department of Health and Human Services: National Center for Health Statistics: Third National Health and Nutritional Examination Survey, 1988-1994 NHANES III. Exam Data File Hyattsville, MD: Centers for Disease Control and Prevention; 1997.

22. US Department of Health and Human Services: . National Center for Health Statistics: Third National Health and Nutritional Examination Survey, 1988-1994 NHANES III. Serum Leptin Data File Hyattsville, MD: Centers for Disease Control and Prevention; 2002

23. Dillon CF, Hirsch R, Rasch EK, Gu Q: Symptomatic hand osteoarthritis in the United States: prevalence and functional impairment estimates from the third U.S. National Health and Nutrition Examination Survey, 19911994. Am J Phys Med Rehabil 2007, 86:12-21.

24. Rasch EK, Hirsch R, Paulose-Ram R, Hochberg MC: Prevalence of rheumatoid arthritis in persons 60 years of age and older in the United States: effect of different methods of case classification. Arthritis Rheum 2003, 48:917-926.

25. Kanabrocki EL, Hermida RC, Wright M, Young RM, Bremner FW, Third JL, Ryan MD, Ayala DE, Johnson M, Nemchausky BA, Shirazi P, Scheving LE, Olwin JH: Circadian variation of serum leptin in healthy and diabetic men. Chronobiol Int 2001, 18:273-283.

26. Sierra-Johnson J, Romero-Corral A, Lopez-Jimenez F, Gami AS, Sert Kuniyoshi FH, Wolk R, Somers VK: Relation of increased leptin concentrations to history of myocardial infarction and stroke in the United States population. Am J Cardiol 2007, 100:234-239.

27. Ruhl CE, Everhart JE: Relationship of serum leptin concentration with bone mineral density in the United States population. J Bone Miner Res 2002, 17:1896-1903.

28. Ruhl CE, Everhart JE: Leptin concentrations in the United States: relations with demographic and anthropometric measures. Am J Clin Nutr 2001, 74:295-301. 
29. Lissner L, Karlsson C, Lindroos AK, Sjöström L, Carlsson B, Carlsson L, Bengtsson C: Birth weight, adulthood BMl, and subsequent weight gain in relation to leptin levels in Swedish women. Obes Res 1999, 7:150-154.

30. Considine RV, Sinha MK, Heiman ML, Kriauciunas A, Stephens TW, Nyce MR, Ohannesian JP, Marco CC, McKee LJ, Bauer TL: Serum immunoreactiveleptin concentrations in normal-weight and obese humans. N EnglJ Med 1996, 334:292-295.

31. Wiesner G, Vaz M, Collier G, Seals D, Kaye D, Jennings G, Lambert G, Wilkinson D, Esler M: Leptin is released from the human brain: influence of adiposity and gender. J Clin Endocrinol Metab 1999, 84:2270-2274.

32. Maffei M, Halaas J, Ravussin E, Pratley RE, Lee GH, Zhang Y, Fei H, Kim S, Lallone R, Ranganathan S: Leptin levels in human and rodent: measurement of plasma leptin and ob RNA in obese and weightreduced subjects. Nat Med 1995, 1:1155-1161.

33. Saad MF, Damani S, Gingerich RL, Riad-Gabriel MG, Khan A, Boyadjian R, Jinagouda SD, el-Tawil K, Rude RK, Kamdar V: Sexual dimorphism in plasma leptin concentration. J Clin Endocrinol Metab 1997, 82:579-584.

doi:10.1186/ar3864

Cite this article as: Massengale et al:: The relationship between hand osteoarthritis and serum leptin concentration in participants of the Third National Health and Nutrition Examination Survey. Arthritis Research \& Therapy 2012 14:R132.

\section{Submit your next manuscript to BioMed Central and take full advantage of:}

- Convenient online submission

- Thorough peer review

- No space constraints or color figure charges

- Immediate publication on acceptance

- Inclusion in PubMed, CAS, Scopus and Google Scholar

- Research which is freely available for redistribution

Submit your manuscript at www.biomedcentral.com/submit 